\title{
- HOW TO HELP LEARNERS TO IMPROVE THEIR ENGLISH PRONUNCIATION. WHAT RIOPLATENSE SPANISH SPEAKING EFL TEACHERS NEED TO KNOW.
}

\begin{abstract}
Ne može se poreći da postoji potreba za predavanjem izgovora u okviru kurseva engleskog kao stranog jezika. S druge strane, dosta se raspravlja o tome da li treba uključiti fonetiku i fonologiju u predavanje engleskog u osnovnom i srednjem obrazovanju. Čini se da pitanje nije da li predavati izgovor, ili šta predavati, već kako predavati. Iz našeg četrdesetogodišnjeg iskustva možemo reći da je neophodno da nastavnici poseduju znanje iz date oblasti ali i da poznaju metodiku, kako bi odabrali prikladan pristup. To podrazumeva znanje o fonološkom sistemu kako sopstvenog L1 (u ovom slučaju rioplatenskog španskog), tako i o fonološkom sistemu engleskog govora koji se predaje, zajedno sa veštinama koje će aktivirati kod učenika "nove načine razmišljanja i konceptualizovanja reči i rečenica stranog jezika" (Fraser 1999: 5). U ovom radu ćemo porediti ova dva fonološka sistema i komentarisati neke od pristupa koji se mogu primeniti kako bi se kod učenika razvili fonološki koncepti koji mogu dovesti do poboljšanja njihovog izgovora engleskog jezika.

Ključne reči: fonetika, fonologija, ELT, španski, engleski.
\end{abstract}

MARÍA ALICIA MALDONAD0 ${ }^{1}$

\section{INTRODUCTION}

After over 40 years' experience teaching English as a foreign language at all educational levels, out of which 25 were at Teacher Education Programmes and inservice teachers' professional development courses, I can assert that all teachers who aim to help learners to improve their English pronunciation need to have a) expertise in the phonological systems of both English and the native language, b) knowledge of methodology and teaching strategies and c) a positive predisposition to establish

1 Contact information: marilimaldonado@gmail.com 
rapport and help students to learn. In this way, learning will become more meaningful, significant and approachable for learners.

In this paper I will address two main issues: I will compare the Rioplatense Spanish and BBC English phonological systems to identify the areas which present most difficulties for Rioplatense Spanish speakers (RSS) to learn English. Besides, I will describe some teaching strategies that might help these students to develop phonological awareness and improve their English pronunciation.

For the sake of this work, when I speak of Spanish, I will be making reference to Rioplatense Spanish (RS). Rioplatense Spanish is the Spanish dialect spoken in the La Plata river basin area in Argentina (Figure 1), namely Buenos Aires, Santa Fe, Entre Ríos provinces and also in Uruguay.

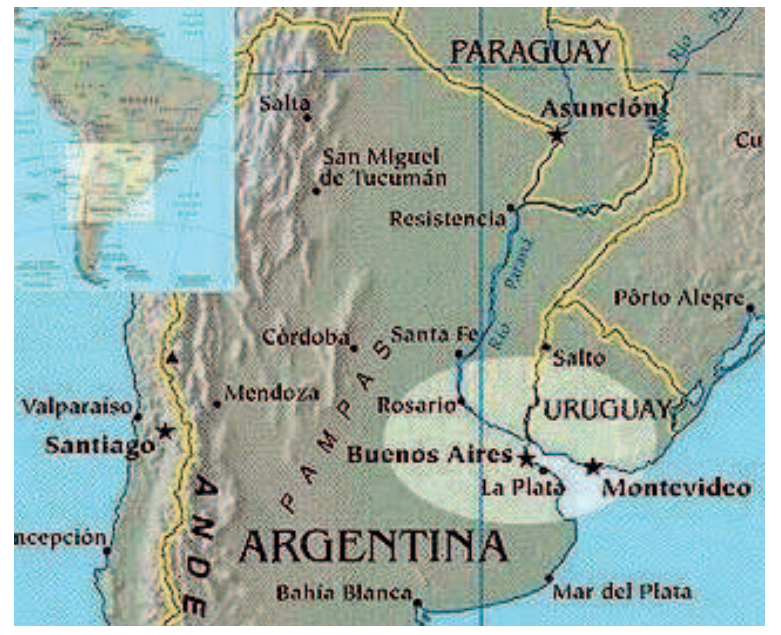

Figure 1. La Plata river basin area in Argentina (HISPANISM0.0RG)

Due to the fact that it is the dialect used in the media, it is widely spread all over Argentina and Uruguay. Therefore we could assert that it is spoken by most of the inhabitants in both countries. In spite of this, we cannot deny the existence of some regional differences and idiolects. In the analysis that follows, we will consider the standard version of Rioplatense Spanish - the variety foreign students are taught when they want to communicate fluently in Argentina.

BBC English is defined by Prof. John Wells in the Longman Pronunciation Dictionary (2008: xvii) as a modernized version of RP. Nevertheless, he points out that "now that BBC admits regional accents among announcers this name has become less appropriate." We understand by BBC English the standard model of correct pronunciation that is taught when speakers of other languages learn English which is not American [we could add Australian, South African, or any other] accent.

RSS teachers who want to teach BBC English to Argentine students need to study the linguistic systems of Spanish and English to detect the areas which students might 
find most difficult. Even though teachers are not expected to focus on the teaching of Phonetics and Phonology per se, we understand that intelligibility in interaction is only possible if individuals at least approach the target model of pronunciation.

In order to find these areas of difficulty, I will compare Rioplatense Spanish and BBC English. In this paper, I will use terms Rioplatense Spanish/Spanish and BBC English/ English interchangeably, always referring to the same accent.

\section{RIOPLATENSE SPANISH AND BBC ENGLISH COMPARED}

There are some characteristics of both languages that cause difficulty for RSS students when they are learning English. First and foremost, these are spelling differences. Spanish is characterized by grapheme-phoneme correspondence, which facilitate pronunciation learning. On the other hand, there is no grapheme-phoneme correspondence in English, which poses a great challenge for Rioplatense Spanish Speakers (RSSs) learning English pronunciation.

Since Spanish is a syllable-timed language, RSSs tend to produce full vowels in all syllables and, thus, they do not produce weak forms of items. RSSs need to learn the rhythm of English and the value of the weak vowels $/ \mathrm{I} /, / \mathrm{v} / \mathrm{and} / \mathrm{o} /$, since they help to give English one of its main characteristics: its stress-timed rhythm.

The flexibility of the Spanish grammar allows Spanish speakers to place the most important piece of information at the end of the utterance. This implies that we usually produce broad focus. On the other hand, English has a stricter grammar system. This makes it necessary for English speakers to mark narrow focus in order to highlight the most relevant piece of information in their utterances.

Both languages share proclaiming and referring tones (Brazil 1994), or falling and rising as these tones are described by Wells (2006), with their generalities as regards meaning. In both cases we associate proclaiming or falling tones with completeness and definiteness and referring or rising tones with incompleteness and evocative value. There are still some differences which bring about misunderstanding when the tones are used wrongly.

\subsection{COMPARING RIOPLATENSE SPANISH AND BBC ENGLISH SEGMENTALS}

\subsubsection{Vowels}

\subsubsection{Monophthongs}

Rioplatense Spanish has five monophthongs whose allophones cover a wide area of articulation. This contrasts with the English monophthongs, which are twelve in number (see Figures 2 and 3).

Finch and Ortiz Lira (1982) highlight the striking difference in number between the twelve pure English vowels and the five Spanish ones. 


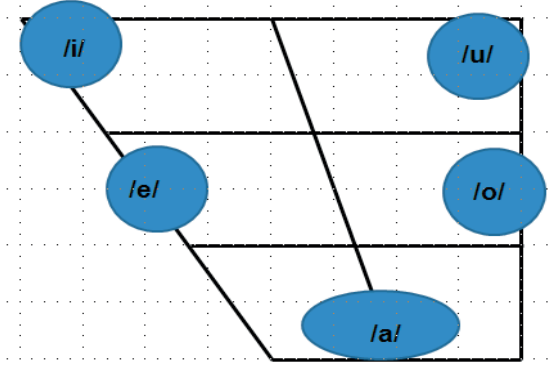

Figure 2. Rioplatense Spanish monophthongs

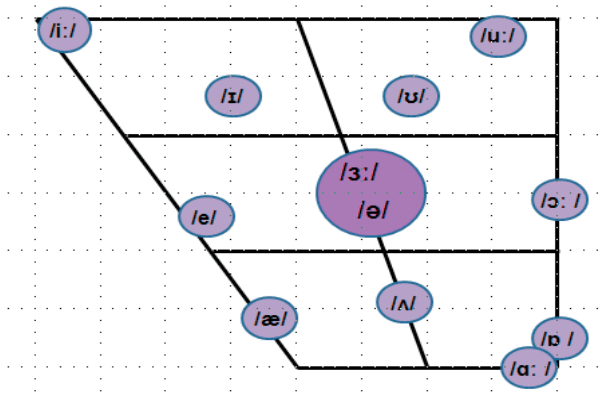

Figure 3. BBC English monophthongs

Escudero and Boersma (2004), claim that "the most obvious effect of phonological transfer at the segmental level concerns the difficulty of perceiving the distinction between two sounds in a second language that are not in phonemic contrast in the native language." Observing Figures 2 and 3 it is easy to understand why RSSs find it so difficult to discriminate between English vowels such as $/ \mathrm{I} /$ and $/ \mathrm{ii}: / ; / \Lambda /$, $/ \mathfrak{a} /$ and $/ \mathrm{a}: /$, or $/$ $\mathrm{u} / \mathrm{and} / \mathrm{v} / \mathrm{.}$

Working with examples of minimal pairsin which words share grammatical category is an excellent way to help students to raise awareness of meaningful differences. Showing RSSs how they generate misunderstanding because of mispronunciation of a vowel sound helps them to perceive the sound contrasts. If we work on reactive teaching, i.e. we react to students' production as a native speaker of English would react, RSSs will be able to perceive their mistake more accurately (Kelly 2003; Fraser 1999, 2006, 2008), e.g. a student says * [aI 'ka:nt li:v wiðaut 'wo:tə] and the teacher answers 'Yes, you can!'. We can make the correction more memorable if we add some humour, e.g. when a student says * [arm 'gəurn raund ðə 'wz:ld pn ə 'fi:p] with the intention of meaning [arm 'gəuin raund ðə 'wз:ld pn ə 'Sip], and the teacher answers 'Poor sheep!'. These examples respond to what is usually called a "shocking technique". Students find their teacher's response so unexpected that they have to draw conclusions as regards it and that helps them to become aware of the difference in meaning immediately. This awareness helps learners to improve their production of the differing sounds.

It is still more difficult for RSSs to perceive and produce central vowels since they do not exist in Rioplatense Spanish. Spanish does not have any vowels produced by raising the central part of the tongue. To help students visualize the phonological concept, I suggest we should use the "see-saw" technique (Kenworthy 1987). It consists in producing a cline between two extreme vowel sounds, e.g. move from /i:/ to /a:/. While students move their tongue, the teacher makes them stop midway and helps them to perceive the position of their articulator. Immediately afterwards we put a name to the sound which reminds learners of its characteristics. Peter Roach (2005) mentions that the long central vowel is widely known as "the hesitation sound" usually spelt 'er'. The schwa /a/, or short central vowel is only produced in a string of speech since it never occurs in stressed position. Because of this reason, and because I adhere 
to the wholistic principle presented by Cognitive/Functional Linguistics, I consider it is almost always better to practise pronunciation by producing oral messages. It is in this way that students will become better aware of how their pronunciation mistakes might bring about misunderstanding. Moreover, practising in context, learners will acquire one of the most relevant characteristics of English: its stress-timed rhythm.

Besides the abovementioned techniques, helping students to visualize what they are actually producing instead of what they intend to produce is very helpful as well. Images are a very useful tool to achieve this aim (Figure 4 and Figure 5).

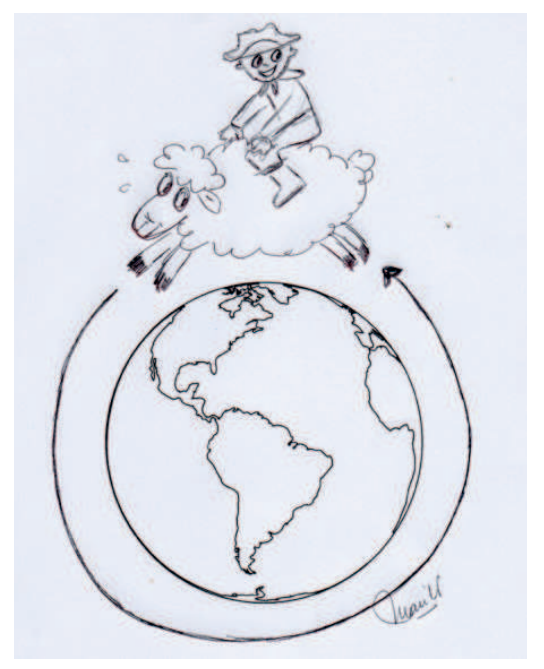

['gəu raund də 'Wз:ld pn a 'si:p]

Figure 4. Visualization of the wrong message: / $\mathrm{si}$ p/ instead of /sip/

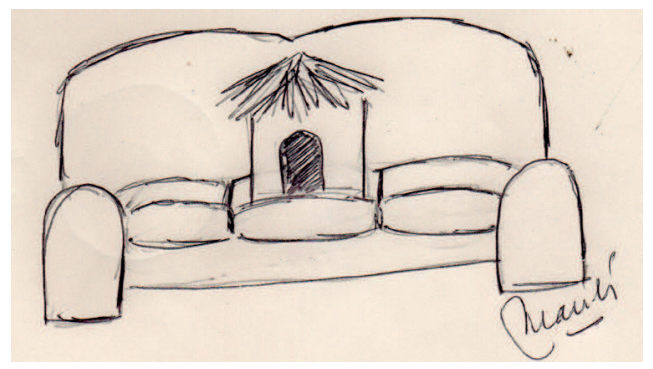

[ðə 'hıt IZ pn ðə 'Səufə]

Figure 4. Visualization of the wrong message: /hıt/ instead of /hæt/

\subsubsection{Diphthongs}

We define diphthongs as vowel sounds consisting of an intentional glide. As a consequence, the first remarkable difference between Rioplatense Spanish and BBC English is the fact that English diphthongs fall into two categories, namely closing and centring, whereas Spanish diphthongs are all closing. Another difference is the fact that English diphthongs have shortened allophones before voiceless consonants or unstressed syllables and Rioplatense Spanish does not have such an allophonic variant.

Both Spanish and English diphthongs are falling because the first element is more prominent than the second one, but Spanish diphthongs are faster and tenser than the English ones. In the production of Spanish diphthongs, the tongue moves towards a closer position reaching the position where the second element is produced. (Figure 6) On the other hand, in English, the tongue moves in the direction of the position where the second sound is produced, but never reaches the point. (Figure 7) 


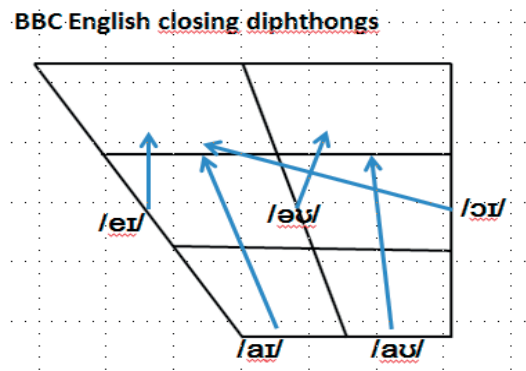

Figure 6. Rioplatense Spanish closing diphthongs

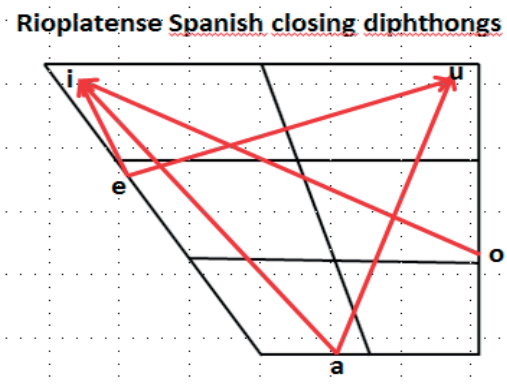

Figure 7. BBC English closing diphthongs

There are no centring diphthongs in Spanish as opposed to English, where there are three gliding towards /o/, though /vo/ is becoming increasingly rare. It is being replaced by the long vowel /o:/ as in poor /po:/. As Collins and Mees (2008) claim "the diphthong /vo/ hardly exists".

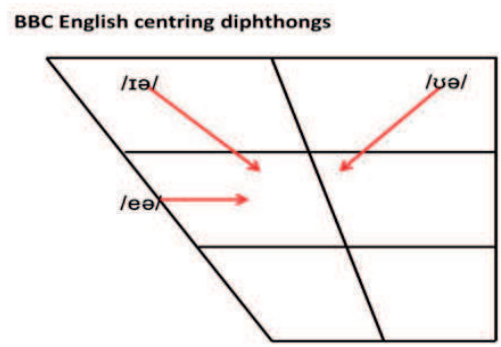

Figure 8. BBC English centring diphthongs

\subsubsection{Triphthongs}

Triphthongs are considered "the most complex English sounds of the vowel type" (Roach 2006). They are the sequence of the five closing diphthongs followed by /o/. Both Roach (2006) and Collins and Mees (2008) explain that the main difficulty for people learning English lies in the reduction, and even absence of the $/ \mathrm{I} / \mathrm{and} / \mathrm{v} /$ in the sequence resulting from what Wells (1982) calls 'smoothing' and Finch and Ortíz Lira (1982) describe as "a form of compression technically known as 'levelling'". Spanish speakers tend to produce three-sound sequences called triphthongs which constitute one syllable each. Due to this conceptual difference, RSSs tend to make a very noticeable tongue movement which is perceived by a BBC English native speaker as an intrusive semivowel in the middle of the sequence. To avoid this strong foreign accent effect, RSSs might omit the /I/ in the sequences/ai/ and /eI/, or let their tongue move slightly in the direction of $/ \mathrm{v} / \mathrm{in} / \mathrm{v} / \mathrm{b}$ efore $/ \mathrm{a} /$. In this latter case, they should try to avoid rounding their lips too much so as not to pronounce /u:/ or even /w/. 


\subsubsection{COMPARING CONSONANTS}

The consonant system of any language seems easier to teach because we can describe place and manner of articulation. We can even draw the articulators and, nowadays with the help of ICT (Information and Communication Technology), show the movement in animated images. The perception of pronunciation differences is also easier. If we ask RSS students to 'sound English', they will surely produce some characteristic features of English consonants such as aspiration of plosives, darkening of the lateral or production of a post-alveolar approximant instead of a trill. This can be a starting point to teach the English consonant system, but there is much more to be displayed if we intend to teach accurate pronunciation.

If we compare Rioplatense Spanish consonants and the BBC English ones, we will be able to identify the most troublesome areas for RSS to learn. (See Figure 9)
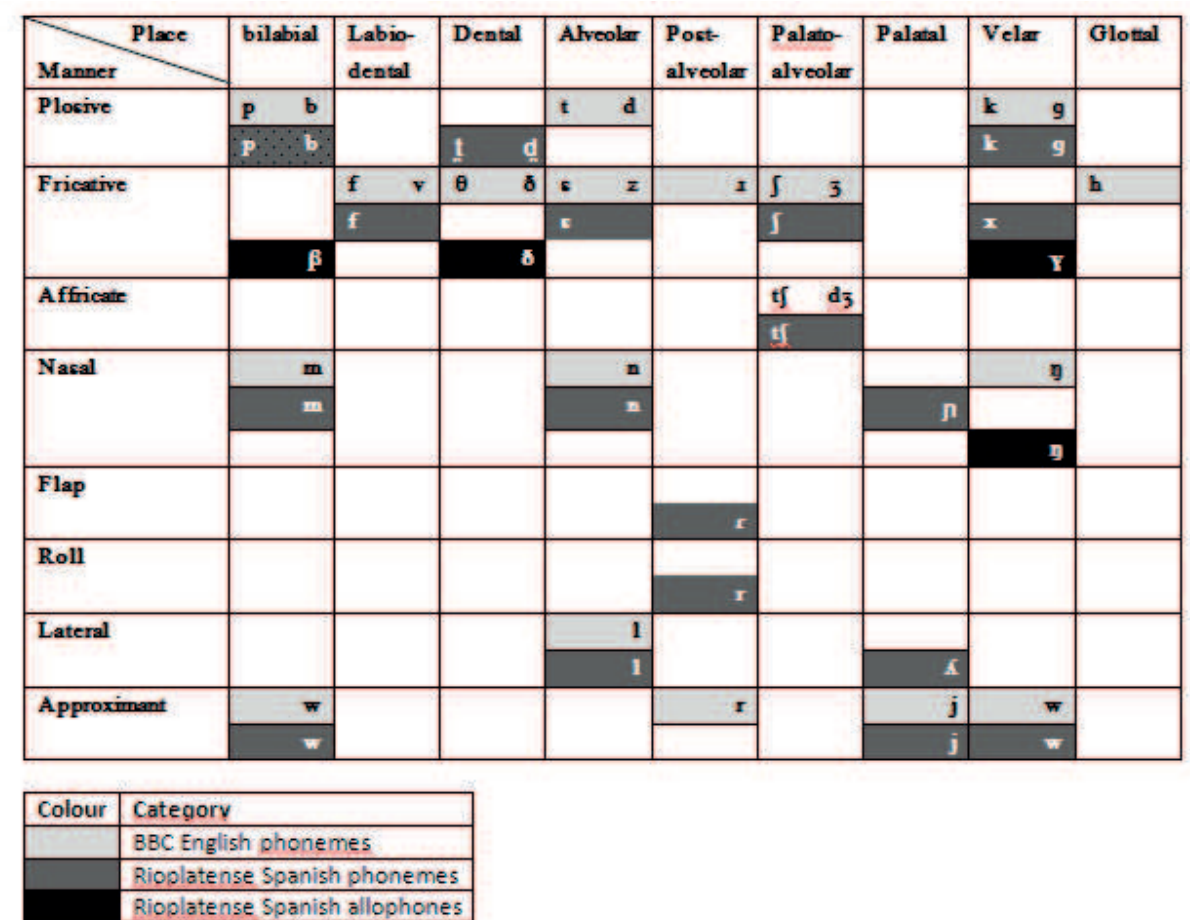

Figure 9. English and Spanish consonant systems compared

Observing the chart, we can perceive that there is numerical correspondence between English and Spanish plosives, nasals and laterals. A relevant contrast can be seen between English and Spanish fricatives. We find four fricatives, which are paired in voiced-voiceless phonemes in English, in contrast with four voiceless fricatives in Spanish. (We can add three voiced fricatives which result from allophonic variants of

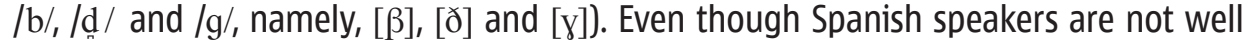


aware of the difference between the phonemes and their allophonic variants, they can produce the sounds. Another sound RSSs get to know, even though they do not normally use it, is $/ \theta /$. This sound is taught for the sake of developing literacy skills at early school stages. When teachers introduce the letter ' $z$ ' they teach students the Peninsular Spanish sound when they say zapato (shoe), zanahoria (carrot), zorro (fox) to make the difference between the letters ' $z$ ' and ' $s$ '. This will enable informed teachers to help learners to become aware of the characteristics of the phonemes in order to identify them when heard and to produce them in due contexts.

Spanish does not have consonants which can function as syllabic nuclei (i.e. consonants that take syllabic value). As a consequence, students tend to add an extra /ə/-like sound in words such as bottle* [bptəl] for ['bptl], or apple*[æpəl] for ['æpl]. Only conscious continuous practice can help students to get these allophonic variants right.

Another difference which poses difficulty for RSSs to be accurate is the lack of initial clusters beginning with $/ \mathrm{s} /+$ consonant in Spanish. RSS students tend to add an extra /o/-like sound before the cluster, thus mispronouncing words such as speak *[os'pi:k] for [spi:k], stay *[əs'tei] for [steI], etc. In order to put this right, learners are encouraged to either lengthen the initial /s/ (i.e. to produce [sssspi:k] and [sssster]; or to make use of junction to avoid the addition of the /a/ [i.e. [ðə 'stjudnt] or [tu 'spi:k]. Recalling these examples whenever students make a mistake with the clusters will help them to construe their concepts and embody the correct pronunciation.

\subsubsection{Plosives}

English and Spanish share the same number of plosives. And these plosives are paired into voiced and voiceless counterparts. While Spanish voiced plosives are fully voiced in all positions, they are only fully voiced in English when surrounded by voiced sounds.

As regards articulation, bilabial and velar plosives are the same while RS has dental plosives and BBCE comprises alveolar plosives. This is one of the reasons why RSSs articulate / $/$ / wrongly, mainly when it is in initial position in the word. On the other hand, RS plosives $/ \mathrm{b} /, / \mathrm{d} /, / \mathrm{g} /$ are realised as the fricatives [ $\beta]$, [ð], [y] respectively when the sounds appear in intervocalic positions, e.g when they say dado (dice) [d aðo], barbijo (surgical mask) [barßixo] or galgo (greyhound) [galyo].

English voiceless plosives have aspirated release when they are in initial stressed position in a syllable. Spanish does not have such aspirated plosives, and we don't find devoiced semivowels following voiceless plosives in such position, either. In order to help RSS learners visualize the production of these allophones Kelly (2003) and Underhill (1994) suggest putting a thin paper in front of our mouths for it to move when we produce the syllables described, or placing a lighted match to see how the flame flickers.

The correct production of aspirated voiceless plosives will help learners of BBC English to make and perceive the distinction between word sequences such as might earn - my turn / pea stalks - peace talks.

Final consonant clusters are only found in English. Because of this, RSSs tend not to pronounce the final consonant and produce [restəron] instead of ['restərpnt], or they add $\mathrm{a} / \mathrm{I} / \mathrm{or} / \mathrm{a} /$ between the consonants in the cluster. They say *[pa:kid] instead of [pa:kt]. 


\subsubsection{Nasals}

The $/ \mathrm{m} /$ presents no articulation problem since it exists both in Rioplatense Spanish and BBC English. The special difficulty appears as regards its distribution. There are only a few loanwords in Spanish ending with / $/$ /, so RSSs tend to produce a $/ \mathrm{n} /$ instead. We can profit from the grapheme-phoneme correspondence we find in Spanish and ask students to pay attention to spelling to help them to produce the final consonant correctly.

Even though the $/ \mathrm{m} /$ only occurs before homorganic consonants in Spanish, RSS learners of English will not find it difficult to pronounce this sound before $/ \mathrm{f} /$ and $/ \mathrm{v} /$ since both in English and Spanish we have labio-dental assimilation of the nasal sound e.g. confite (sweet) [kom'fite] and invitación (invitation) [imvitasi'on].

The $/ \mathrm{n} /$ has the same articulation and distribution in both languages, so it presents no difficulty for RSSs to produce the English sound.

Even though the $/ \mathrm{y} /$ is not a Spanish phoneme, it is realised as an allophonic variant of $/ \mathrm{n} /$ in words like ['tango] and ['tanke]. Teachers can use the syllable-timed characteristic of Spanish to ask students to syllabify the word and stop when reaching the end of the first syllable. Students will have the feeling of how the $/ \mathrm{y} /$ is produced. Students will have less problems producing this sound in final position, while they will need more practice to produce the sound when followed by vowels.

\subsubsection{Fricatives}

As it was stated before, there is a relevant contrast between the four English fricatives paired in voiced-voiceless phonemes and the four voiceless fricatives in Spanish. Because of this, RSS have special problems when they try to produce voiced English fricatives.

Even though $/ \mathrm{v} /$ does not exist in Spanish because it is replaced by $[\beta]$, the allophonic variant of / $b$ / which is used indistinctly when reading ' $b$ ' and ' $v$ ', RSS have the concept of $/ \mathrm{v} /$ because the contrast between $/ \mathrm{b} /$ and $/ \mathrm{v} /$ is emphasized in initial stages of literacy development to teach the spelling of words like 'varón' (man) and 'barón' (baron). This helps teachers to exemplify the sound more easily.

Aspecial point is to be made when we teach/ठ//.Since in Rioplatense Spanish we produce dental plosives instead of the English alveolar plosives, and [ð] is an allophonic variant of / $\mathrm{d} /$ mainly in intervocalic position (e.g. dado (dice) ['daðo], cada (each) ['kaða]) RSSs tend to produce $a / d /$ in initial position instead of the $/ \delta /$, and a $/ \delta /$ in intervocalic position instead of $\mathrm{a} / \mathrm{d} /$ (e.g.*[di ' 'əuðə] instead of [ði 'əudə] for 'the odour'). In order to help students to produce the correct sounds in the correct position, we should try to ask them to produce them in meaningful contexts in an alternated way (e.g. [ði 'əuldə ði 'æd $\Lambda$ lt ðə mə: 'mbdərət])

\subsubsection{Approximants}

Collins and Mees (2008: 273) define approximant as "a manner of articulation produced with the articulators sufficiently apart for there to be no audible friction". They categorise them into central and lateral approximants. All of them only occur before a vowel sound. 
While English has a post-alveolar approximant /r/, also called frictionless continuant because the tip of the tongue never touches the roof of the mouth, we find that Spanish has a flap /r/ and a post-alveolar roll or trill in its consonant system. RSS make a distinction between pero (but) and perro (dog) whereas English speakers don't produce the trill. But this represents difficulty for English speakers to learn Spanish and not the other way around.

The consonants $/ \mathrm{j} /$ and $/ \mathrm{w} /$ are phonologically like consonants and phonetically like vowels. This is the reason why they used to be defined as semi-vowels. Peter Roach (2005) asserts that the articulation of $/ \mathrm{j} /$ is practically the same as that of $/ \mathrm{i} i /$ and the articulation of /w/ is very similar to that of /u:/. Nevertheless, he also claims that we use both phonemes as consonants. They always occur before a vowel and they can be devoiced.

While $/ \mathrm{j} /$ has no relevant difference between English and Spanish except for the greater muscular tension RSSs produce, we can describe the Spanish /w/ as stressing the velar quality of the sound in contrast with the labial quality emphasis perceived in the English sound. This difference brings about a mistaken production of the English sound by RSSs. They tend to produce a stop or a fricative velar sound before the $/ \mathrm{w} /$ in familiar speech e.g. aguanto (support) [a'ywanto] and thus, they are bound to transfer this habit to English utterances. A good technique to put this right is to ask students to produce a sequence of syllables starting with $/ \mathrm{w} /$ and followed by the five Spanish vowels, i.e. /wa/, /we/, /wi/, /wo/, /wu/. When they pronounce this last syllable they actually become aware of the difference between the approximant $/ \mathrm{w} /$ and the vowel sound /u:/. To improve accuracy, it is useful to ask students to compete in preparing the longest possible sentence using this approximant. (A group of students of mine created the sentence Why was Wendy waiting when we walked with wolves on Wednesday?) They will have fun and they will be practicing both reception and production of the sound. Getting students involved in the visualization of differences, embodiment of new knowledge and emotion commitment, gives them a great chance to succeed in improving accuracy.

As regards the lateral approximant /1/, both English and Spanish share the characteristics of the clear $/ 1 /$, i.e. the sound produced in initial or medial position. 0 n the other hand, Spanish lacks the strong version of [ $\mathrm{f}$ ] and RSSs understand this allophonic version as 'typical of English'. Due to this perception, they tend to overgeneralize the use of $[\mathrm{t}]$ producing it everywhere in utterances for the sake of "sounding more Englishlike". The accurate differentiation and production of the two versions is quite easy to put right by using utterances which include both, e.g. Louise loves living all alone in the middle of the field. Besides highlighting their different phonological characteristics, we can explain phonotactics to aid accurate pronunciation of them.

\subsubsection{Intonation}

I cannot close this overview without some reference to the relevance intonation has in meaning conveyance. Although it deserves a thorough description in another paper, I will just include a slight reference to its treatment. Tonality, tonicity and tone trace the realization of the different functions of intonation (Wells 2006). It is not what we say but the way in which we say it what makes a difference (Underhill 1994; Kelly 2003). The use of meaningful messages varying dramatically due to diverse intonation helps raising 
awareness in students. We resort to critical thinking and guide students into discovery. e.g. when we focus their attention on the difference in meaning between $\| A$ 'woman $\|$ without 'her $\|$ 'man is 'nothing $\|$ and $\| A$ ' woman with'out her 'man $\|$ is 'nothing $\|$

Another way of helping students is using humour. A good pun (see Fig. 10) can enlighten the learners.

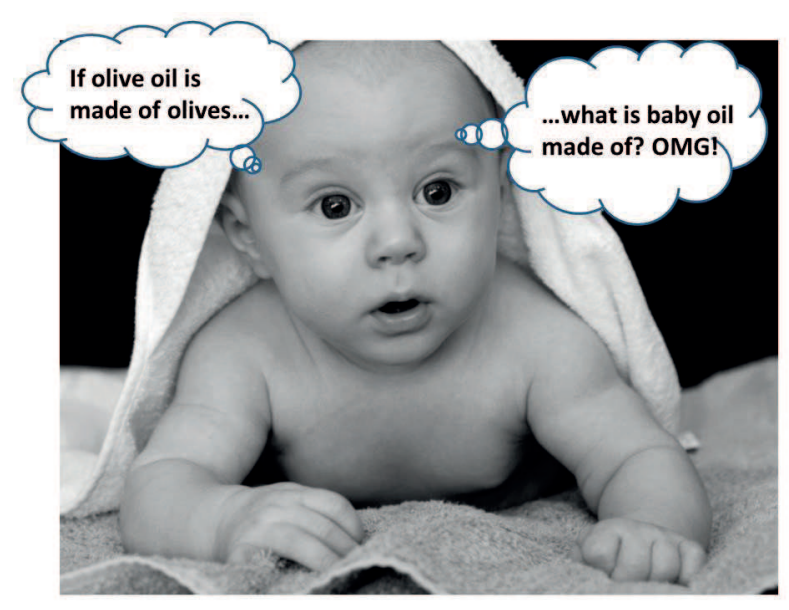

Figure 10. A phonological pun

This joke can aid raise awareness as regards the correct use of word stress. Students will understand the difference between 'baby 'oil (oil made out of babies) and 'baby oil (oil to be used with babies). This joke also gives teachers the possibility of identifying the use of a referring tone anticipating the conclusion of the idea produced with a proclaiming tone. It can also be noted the use of broad focus in the first utterance (the intonation nucleus is produced on the last content word) and narrow focus in the second one (focus on 'baby', which is not the last content word).

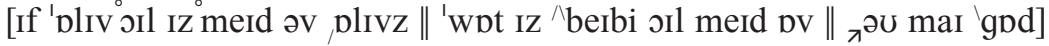

\section{TEACHING PRIORITIES}

In order to plan good lessons integrating pronunciation as an essential issue in meaning conveyance, teachers need to be aware of how to grade the demand they pose on learners. Different phoneticians see priorities from different perspectives. Cruttenden (2001) bases the identification of priorities on frequency of occurrence and word categories. He explains that we need to pay special attention to words students will frequently encounter and use. At the same time, he asserts that mistaking the pronunciation of a sound is more relevant when the change brings about misunderstanding because both words (the one produced and the one the

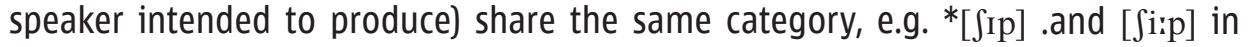
Figure 4. 
Kenworthy (1987) and Collins and Mees (2008) share similar hierarchies of errors. They describe three categories each, as presented in Figure 11.

In both cases they consider that errors that affect intelligibility are to be considered as the most relevant ones. In terms of teaching principles, they have to be taught focally and students should be penalized in case they do not achieve the correct pronunciation.

Secondly, we find errors which do not affect intelligibility but can give rise to irritation or amusement. We can include within this category those errors which give speech a gross foreign accent.

Last, but not least, are those errors which neither affect comprehensibility nor provoke any kind of reaction. They might even pass unnoticed because people who use a particular English accent speak like that, or the feature is "close enough" to the native feature and thus, native speakers can be used to hearing them. In this case, the features are only to be focused upon if the learner is somebody who is being trained to become a teacher of English or plans to work on the basis of his/her language accuracy.

\begin{tabular}{|l|l|}
\hline Collins \& Mees (2001) & Kenworthy (1987) \\
\hline $\begin{array}{l}\text { Category 1: } \\
\text { Errors which lead to a breakdown in } \\
\text { intelligibility }\end{array}$ & $\begin{array}{l}\text { High Priority: } \\
\text { Errors which are vital for intelligibility }\end{array}$ \\
\hline $\begin{array}{l}\text { Category 2: } \\
\text { Errors which give rise to irritation or } \\
\text { amusement. }\end{array}$ & $\begin{array}{l}\text { Low Priority: } \\
\text { Errors which often do not affect } \\
\text { intelligibility, e.g. sounds which occur } \\
\text { relatively rarely, such as /3/. }\end{array}$ \\
\hline $\begin{array}{l}\text { Category 3: } \\
\text { Errors which provoke few such reactions } \\
\text { and may even pass unnoticed. }\end{array}$ & $\begin{array}{l}\text { Optional attention: } \\
\text { Errors which might contribute to a } \\
\text { very noticeable foreign accent, but } \\
\text { native speakers are used to them either } \\
\text { because: } \\
\text { 1.They exist in some regional accents or } \\
\text { varieties of English. } \\
\text { 2.The feature is "close enough" to the } \\
\text { native feature. }\end{array}$ \\
\hline
\end{tabular}

Figure 11. Hierarchies of error compared

\section{CONCLUSION}

Quoting Recamán (1979: 66), we could assert that teachers "should possess 'a sound knowledge' of the phonological and phonetic characteristics both of English and Spanish, a pronunciation of the target language close to the model chosen, and the ability to predict errors and use adequate techniques of correction." Helping students to acquire a 
good pronunciation, we will be teaching them how to convey meaning correctly because pronunciation is an integral part of meaning, as well as grammar and syntax.

Teachers are not supposed to stop lessons just to practise pronunciation points, but they are expected to plan lessons in which students will have learning experiences which are meaningful and significant. This will help learners to build their English conceptual frame and use the new language with a comprehensible native-like pronunciation.

\section{REFERENCES}

Brazil, D. 1994. Pronunciation for Advanced Learners of English. Teacher's Book. Cambridge: Cambridge University Press.

Brazil, D. 1994. Pronunciation for Advanced Learners of English. Student's Book. Cambridge: Cambridge University Press.

Collins, V. and I. Mees. 2008. Practical Phonetics and Phonology. A resource book for students. $2^{\text {nd }}$ edition. Abingdon: Routledge.

Cruttenden, A. 2001. Gimson's Pronunciation of English. $6^{\text {th }}$ revised edition. London: Arnold.

Escudero, P. and P.Boersma. 2004. Bridging the gap between L2 speech perception research and phonological theory. Studies in Second Language Acquisition 26, 551-585.

Finch, D. and H. Ortiz Lira. 1982. A Course in English Phonetics for Spanish Speakers. London: Heinemann.

Fraser, H. 1999. ESL Pronunciation Teaching: Could it be more effective? [Internet]. Available at: https://www.cdu.edu.au/walking_talking_texts/documents/PronunciationpaperbyHelenFraser.doc [08.10.2015].

Fraser, H. 2006. Helping teachers help students with pronunciation: A cognitive approach. Australia: University of New England. [Internet]. Available at: http://www. ameprc.mq.edu.au/docs/prospect_journal/volume_21_no_1/21_1_5_Fraser.pdf [08.12.2015].

Fraser, H. 2008. Cognitive Theory as a Tool for Teaching Pronunciation. University of New England. Australia. [Internet]. Available at: http://www.linse.uni-due.de/lauddownloadliste/articles/cognitive-theory-as-a-tool-for-teaching-pronunciation. html?file=tl_files/laud/A728_Fraser_komplett.pdf [08.08.2015].

hispanismo.org. Español Rioplatense. [Internet]. Available at: http://hispanismo.org/ hispanoamerica/18089-espanol-rioplatense.html [07.12. 2017].

Kelly, G. 2003. How to Teach Pronunciation. Harlow: Longman.

Kenworthy, J. 1988. Teaching English Pronunciation. Harlow: Longman.

Recaman, M. 1979. A comparative study of the phonological structures of English and Spanish. Unpublished manuscript.

Roach, P. 2005. English Phonetics and Phonology. A practical course. Cambridge: Cambridge University Press.

Underhill, A. 1994. Sound Foundations. Oxford: Heinemann.

Wells, J. 1982. Accents of English. Cambridge: Cambridge University Press.

Wells, J. 2006. English Intonation: An Introduction. Cambridge: Cambridge University Press. 


\section{SUMMARY}

\section{HOW TO HELP LEARNERS TO IMPROVE THEIR ENGLISH PRONUNCIATION: WHAT RIOPLATENSE SPANISH SPEAKING EFL TEACHERS NEED TO KNOW}

We cannot deny the need for teaching pronunciation in EFL courses. Still, there is much discussion as regards whether to include phonetics and phonology in the EFL primary and secondary classrooms. The issue seems to be not whether to teach pronunciation, or what to teach, but rather how to teach it.

From my teaching experience of over 40 years, I can claim that teachers need to have the expertise in the subject and the methodology knowledge that enable them to choose adequate strategies. This implies having knowledge of the phonological systems of both their L1 (in this case, Rioplatense Spanish) and the English accent they are expected to teach, together with the skills to activate in learners "new ways of thinking about or conceptualizing words and sentences in the new language" (Fraser 1999: 5).

In this work I will compare both phonological systems and comment on some useful strategies that can be implemented to help students develop phonological concepts that can foster improvement of their English pronunciation.

KEYWORDS: Phonetics, Phonology, ELT, Spanish, English.

ARTICLE INFO:

Original research article

Received: May 10, 2018

Revised: January 31, 2019

Accepted: February 5, 2019 